\title{
What's in a name? The case for protecting the reputation of businesses under Article 1 Protocol 1 of the European Convention on Human Rights
}

Article

Accepted Version

Coe, P. and Brown, J. (2020) What's in a name? The case for protecting the reputation of businesses under Article 1 Protocol 1 of the European Convention on Human Rights. Journal of European Tort Law, 10 (3). pp. 286-315. ISSN 1868-9612 doi: https://doi.org/10.1515/jetl-2019-0123 Available at https://centaur.reading.ac.uk/86811/

It is advisable to refer to the publisher's version if you intend to cite from the work. See Guidance on citing.

To link to this article DOI: http://dx.doi.org/10.1515/jetl-2019-0123

Publisher: De Gruyter

All outputs in CentAUR are protected by Intellectual Property Rights law, including copyright law. Copyright and IPR is retained by the creators or other copyright holders. Terms and conditions for use of this material are defined in the End User Agreement. 


\section{CentAUR}

Central Archive at the University of Reading

Reading's research outputs online 


\title{
Articles
}

Peter Coe and James Brown

\section{What's in a Name? The Case for Protecting the Reputation of Businesses under Article 1 Protocol 1 of the European Convention on Human Rights}

Corresponding author: Peter Coe, Lecturer in Law, University of Reading; Research Associate, Information Law and Policy Centre, Institute of Advanced Legal Studies, University of London, UK, E-Mail: peter.coe@ reading.ac.uk

James Brown, Reader in Property Law, Aston Law School, Aston University, UK, E-Mail: j.p.brown1@aston.ac.uk

\begin{abstract}
This article approaches corporate reputation from an English law perspective. It argues that corporate reputation is at least as important as individual reputation, as it is not only vital for the health and prosperity of businesses themselves (whether large or small), but also for the communities within which they operate. Following analysis of conflicting jurisprudence from the European Court of Human Rights, which has led to a lack of clarity within English law, this paper contends that business reputation should be subsumed within the concept of property. Such an approach would then enable businesses to avail themselves of a positive right to the protection of reputation, as property, under Article 1 Protocol 1 of the European Convention of Human Rights.
\end{abstract}

\section{Introduction}

In his excellent Journal of Media Law article entitled 'Corporate Reputation under the European Convention on Human Rights' David Acheson persuasively argues, inter alia, that Article 1 Protocol 1 (A1P1) does not and should not protect corporate reputation. ${ }^{1}$ This article 
offers a rejoinder to this argument. It contends that, as it currently stands, English defamation law may be vulnerable to challenge under the European Convention on Human Rights (ECHR) as it only protects corporate reputation where, pursuant to sec 1(2) of the Defamation Act 2013, the claimant is able to establish that they have suffered, or that they are likely to suffer, serious financial loss as a result of the alleged defamatory statement(s). Whether the 2013 Act complies with the ECHR depends on whether corporate reputation is protected as 'property' under A1P1. Contrary to Acheson's view, this article argues that a company's right to reputation should be subsumed within the concept of reputation as property and should, therefore, enable corporations to avail themselves of a positive right to the protection of reputation, as property, under A1P1. This is because, as set out in section II, reputation is clearly an asset of tangible value for companies. Consequently, damage caused to reputation can have a huge detrimental impact on the prosperity and health of not only the companies themselves but, also, the communities within which they are located and the wider economy. As companies can benefit from ECHR rights, ${ }^{2}$ it argues that it is surely right that legal mechanisms exist to enable corporations to protect this vital asset. However, despite the importance of corporate reputation the ability of companies to protect their reputation, by virtue of a positive Convention right pursuant to A1P1, as opposed to reliance on Article 10 ECHR, is controversial and is subject to equivocal European Court of Human Rights (ECtHR) jurisprudence that has led to confusion within English law.

This article begins at section II, which sets out what is meant by 'corporate reputation' and provides analysis of its value to both companies and society. Section III explains why, despite having historic roots, the right of corporations to sue in defamation is

\footnotetext{
${ }^{1}$ D Acheson, Corporate Reputation under the European Convention on Human Rights (2018) 10 Journal of Media Law (JML) 49.

${ }^{2}$ See section VI below.
} 
controversial. This leads into section IV which discusses the concept of the right to reputation as property. Specifically, this section argues that the notion of property is dynamic and is inextricably linked to societal development and change. It is contended that this provides conceptual support for the argument that reputation can be protected through the medium of the 'property concept'. Section V explains why a positive right to corporate reputation, protected by virtue of A1P1, is preferable to it being merely a permissible justification for restricting free speech. Section VI provides analysis of the ECtHR's equivocal case law on this and why this has led to confusion within an English law context. Finally, section VII concludes the article by submitting what the preferred position in respect of the protection of reputation as property should be.

\section{What's in a name? The value of corporate reputation}

\section{A What is meant by corporate reputation?}

As will become evident below, scholarship relating to the reputation of companies, within a variety of disciplines, commonly refers to 'corporate reputation' as a term of reference. For the sake of clarity, and for the purpose of this article, corporate reputation relates to the reputation of any 'body' that trades for profit. ${ }^{3}$ Thus, it encapsulates the entire spectrum of corporate entities, from limited companies and limited liability partnerships, including sole traders and small firms, up to multi-national public limited companies (PLCs).

\section{B The value of corporate reputation}

Large companies are at the forefront of the economy, society and politics. The senior officers of these organisations are, very often, closely allied to the government of the day and, as a

\footnotetext{
${ }^{3}$ See sec 1(2) Defamation Act 2013.
} 
result, their views and preferences have the potential to influence policy and ministerial decisions. ${ }^{4}$ Accordingly, in Jameel $v$ Wall Street Journal Europe Sprl (Jameel) ${ }^{5}$ Baroness

Hale stated that 'the power wielded by multi-national corporations is enormous and growing' and that the ability to criticise large companies 'may be at least as important in a democracy as the freedom to criticise the government' ${ }^{6}$

Conversely, notwithstanding Baroness Hale's comments, providing companies with the mechanisms to protect their reputation is also extremely important. Arguably, the need for such a mechanism is particularly acute in the context of smaller companies, such as sole traders and small partnerships. As discussed below, these organisations are not only, very often, inextricably linked to, and embedded within, their local communities, but do not have the same financial, marketing and public relations resources to absorb attacks on their reputation as compared to larger companies. Consequently, a statement that negatively affects the reputation of a small company could cause it severe or even fatal damage. ${ }^{7}$

\footnotetext{
${ }^{4}$ For example, in 2010, the Conservative and Liberal Democrat coalition government announced the creation of a Business Advisory Group, consisting of industry leaders, to assist the Prime Minister and senior ministers with 'high level' business and economic advice. The group operated until 2016:

<https://www.gov.uk/government/news/business-advisory-group-announced>. In 2017 the government set up a similar group to advise on Brexit: <https://www.ft.com/content/67001056-5b39-11e7-9bc8-8055f264aa8b > both accessed 27.9.2019. See also, $P$ Coe, The Defamation Act 2013: we need to talk about corporate reputation (2015) Journal of Business Law (4) 313-333, 313 (JBL); P Coe, The Value of Corporate Reputation and the Defamation Act 2013: A brave New World or Road to Ruin? (2013) 18 Communications Law (Comms Law) 112,112 .

${ }^{5}[2007] 1$ AC 359.

${ }^{6}$ Ibid para 158.

${ }^{7}$ This argument, and the fragility of small companies when it comes to reputational damage, is supported by the 2005 Australian uniform defamation reforms which, as discussed at section III below, removed the right to sue for defamation from companies with ten or more employees. The Standing Committee of Attorneys-General recognised that small, for-profit bodies, may be disproportionately affected by a defamatory publication and less likely to weather its consequences. It therefore recognises the need for smaller entities to be able to protect themselves: Defamation Act 2005 (NSW, Qld, Vic, SA, Tas) sec 9; Defamation Act 2006 (NT) sec 9; Civil Law (Wrongs) Act 2002 (ACT) sec 121; New South Wales Government, Statutory Review Defamation Act 2005, June 2018, para 2.8.
} 
Thus, the performance of economies and the continued social and economic development of communities are inextricably linked to corporate success. ${ }^{8}$ This link is underlined further by sec 172(1)(d) of the Companies Act 2006, which requires directors to take account of 'the impact of the company's operations on the community and the environment'. Although, as Carney states, the notion of 'community' is, potentially, amorphous, ${ }^{9}$ it can be regarded as including the people, businesses and institutions located in the vicinity within which the company is based..$^{10}$ Indeed, according to Keay, having regard for the community: ${ }^{11}$

...might manifest itself in a number of ways, such as a donation to a local cause or refraining from actions which might deleteriously affect the community...[D]irectors...have to justify any such action as enhancing the success of the company. This does not...mean that success has to be reduced to monetary terms. Having an input in the community might be seen as contributing to the success of the company as a respected local firm, and part of its role as a good citizen. This might enhance its reputation, which could arguably contribute to the company's success $^{12} \ldots$ [To the contrary a] company might decline to take on a project that despite being potentially profitable could alienate the local or wider community and lead to the entity being derided, and see its reputation diminish.

Despite the importance of reputation to a company and its community, it remains difficult to define and has been described in a myriad of ways. ${ }^{13}$ For example, it is considered to be a

\footnotetext{
${ }^{8}$ J Smythe/C Dorward/J Reback, Corporate Reputation: Managing the New Strategic Asset (1992), 4. An example of such a link is the car manufacturing industry in the Midlands and North East of England. If, for example, Jaguar Land Rover (Solihull and Wolverhampton) or Nissan (Sunderland) were to suffer the same sort of damage to their reputation in respect of models manufactured at these plants as Toyota did between 2009 to 2010 when it had to recall twelve million vehicles worldwide, or Volkswagen did in relation to the emissions scandal, which it is estimated has already cost the company $\$ 30$ billion, it could have a huge impact on sales and production which, in turn, could damage the local economies in which they are based.

${ }^{9}$ W Carney, Does Defining Constituencies Matter? (1990) 59 University of Cincinnati Law Review (UCLR) $385,414$.

${ }^{10}$ A Keay, Directors' Duties (2nd edn 2014) 155.

${ }^{11}$ Ibid 157.

${ }^{12}$ Ibid 156.

${ }^{13}$ P Coe (2015) 4 JBL 313, 314-315.
} 
'multi-stakeholder concept that is reflected in the perceptions that stakeholders have of an organisation. ${ }^{, 14}$ It has also been defined as the 'perceptual representation of a company's past actions and future prospects that describes the firm's overall appeal to all of its key constituents when compared with other leading rivals. ${ }^{15}$ Regardless of the definition adopted, clearly reputation is valuable. ${ }^{16}$ Indeed, in Jameel, significantly, Lord Bingham, Lord Hope and Lord Scott all agreed that reputation is a thing of value, ${ }^{17}$ and, more poignantly, Lord Hoffmann stated that it is an asset as it attracts customers. ${ }^{18}$ In Dixon v Holden it was held that reputation is potentially more valuable than other property. ${ }^{19}$

This 'value' attached to corporate reputation is illustrated by a number of real-world examples. According to the Reputation Institute's 2019 Global RepTrak 100 Report, Rolex and Lego are the world's top two most reputable companies. ${ }^{20}$ The report recognises a clear link between reputation and consumer support for a product or service. Thus, for instance, a score of 70-79 translates to $60 \%$ of consumers willing to buy the product or use the service. ${ }^{21}$ Arguably the most explicit and obvious way to evaluate and quantify the value of reputation to corporations is through examples of incidents that have damaged reputations, and have, consequently, had an impact on financial performance. ${ }^{22}$ Although an extreme example, the 2010 Deepwater Horizon oil rig explosion, and subsequent oil spill, is illustrative of this

\footnotetext{
${ }^{14}$ A Smidts/ T Pruyn/ C van Riel, The Impact of Employee Communication and Perceived External Prestige on Organisational Identification (2001) 44 Academy of Management Journal (AMJ) 1051; C Hillenbrand/K Money, Corporate Responsibility and Corporate Reputation: Two Separate Concepts or Two Sides of the Same Coin? (2007) 10 Corporate Reputation Review (CRR) 261, 262; J Larkin, Strategic Reputation Risk Management (2003) 43.

${ }^{15}$ C Fombrun, Reputation: Realizing Value from the Corporate Image (1996) 72.

${ }^{16}$ It has been described as an asset that requires constant care to ensure that it develops positively from generation to generation. See: Smythe (fn 8) 7.

17 [2007] 1 AC 359, [91].

${ }^{18}$ Ibid. [26] per Lord Bingham; [101] per Lord Hope; [120] per Lord Scott. See also: Derbyshire County Council $v$ Times Newspapers Ltd [1993] AC 534, 547.

19 (1868-69) LRR 7 Eq 488, 492.

${ }^{20}$ https://insights.reputationinstitute.com/reptrak-reports/global-reptrak-2019 49-73 accessed 7.10.2019.

${ }^{21}$ Ibid.

${ }^{22}$ A Griffin, New Strategies for Reputation Management (2008) 12 f; Coe (2015) 4 JBL 313, 319 f.
} 
point. ${ }^{23} \mathrm{BP}$ spent more than $\$ 90$ million on public relations in the first three months of the spill alone to attempt to improve its damaged reputation. ${ }^{24}$ Incidentally, Transocean, the company that owned and operated the Deepwater Horizon rig, experienced a $14 \%$ fall in share value in the aftermath of the disaster. ${ }^{25}$

\section{Suing in defamation: historic roots and modern controversy}

In English law a company's right to sue in defamation ${ }^{26}$ can be traced back to the midnineteenth century. ${ }^{27}$ However, due to the Court of Appeal's reasoning, the seminal case on

\footnotetext{
${ }^{23}$ For detailed analysis of the claims brought against BP and the company's compensation scheme, see: $C$ McDonnell, The Gulf Coast Claims Facility and the Deepwater Horizon Litigation: Judicial Regulation of Private Compensation Schemes (2012) 64 Stanford Law Review (SLR) 765; T Schoenbaum, Liability for Damages in Oil Spill Accidents: Evaluating the USA and International Law Regimes in the light of Deepwater Horizon (2012) 24 Journal of Environmental Law (JEL),395.

${ }^{24}$ J Vidal, BP's PR Campaign Fails to Clean up Reputation after Gulf Oil Spill, The Guardian, 14 April 2011, available at: <https www.guardian.co.uk/environment/blog/2011/apr/14/bp-pr-campaign-gulf-oil-spill> accessed 27.9.2019. For the purposes of satisfying the serious harm and serious financial loss tests pursuant to secs 1(1) and (2) of the Defamation Act 2013, according to ReachLocal UK Ltd v Bennett [2015] EMLR 7, money spent on mitigating reputational damage by, for example, employing PR consultants, is evidence of actual or likely serious financial loss.

${ }^{25}$ C Krauss, Oil Spill's Blow to BP's Image May Eclipse Costs, The New York Times, 29 April 2010, available at: $<$ https://www.nytimes.com/2010/04/30/business/30bp.html> accessed 27.9.2019. Although during the Public Bill Committee's Parliamentary Debate on the Defamation Bill, there was debate over whether a fall in share price could demonstrate actual or likely serious harm, with Jonathan Djanogly arguing that it could (a view supported by Holroyd Pearce LJ's judgment in Lewis v Daily Telegraph Limited [1963] 1 QB 340 (CA), 376 and Rose LJ's judgment in McCarthy Stone plc v Daily Telegraph (unrep) 11 November 1993), and Paul Farrelly arguing that it could not, the decision in Collins Stewart v Financial Times Ltd [2005] EMLR 5 has confirmed that it cannot (see also Dillon LJ's judgment in Lonrho v Fayed (No 5) [1994] 1 All ER 188, 196 (a)$(\mathrm{g}))$. Therefore, the accepted position is that a reduction in share price is not sufficient to establish actual or likely serious financial loss as it is not an aspect of goodwill or an asset of the company. For Djanogly and Farrelly's opinions see: Paul Farrelly and Jonathan Djanogly (HC), Parliamentary Debate, Public Bill Committee, Defamation Bill, Fifth Sitting, 26 June 2012, 205 f. See also the views of Ben Gummer at 196.

${ }^{26}$ It is also possible for a company to use malicious falsehood as a cause of action. However, in order to maintain such an action, the claimant must show that: (i) the defendant published to third parties words which are false; (ii) that they refer to the claimant, or their property or their business; (iii) that they were published maliciously; and (iv) that special damage has followed as a direct and natural result of their publication. Because the requirements for establishing a claim for malicious falsehood are significantly more onerous than defamation, it is rarely used. Consequently, it is beyond the scope of this article. See generally: A Mullis/R Parkes QC (eds) Gatley on Libel and Slander (12 edn 2013) paras 21.1 - 21.3.

${ }^{27}$ See The Metropolitan Saloon Omnibus Company (Limited) v Hawkins (1859) 4 Hurlstone \& Norman Exchequer Reports (H\&N) 87, 90 in which Pollock CB stated: 'That a corporation at common law can sue in respect of a libel there is no doubt.'
} 
the right is South Hetton Coal Co Ltd v North-Eastern News Association Ltd. ${ }^{28}$ The Court decided that a corporation may sue for a libellous statement that is calculated to injure it in respect of its business, and may do so without proof of special damage. ${ }^{29}$ The Court found unanimously in favour of the claimant by rejecting the defendant's argument that a corporation had no personal character and could, as a result, not sue in defamation, with Lord Esher MR determining that the law of libel is one and the same for all claimants. ${ }^{30}$ Despite Lord Reid in Rubber Improvement $v$ Daily Telegraph ${ }^{31}$ stating that a company cannot be injured in its feelings, only in its pocket, ${ }^{32}$ the South Hetton principle was reaffirmed by the House of Lords in Derbyshire County Council v Times Newspapers Ltd. ${ }^{33}$ According to Lord Keith it is 'clearly establish[ed] that a trading corporation is entitled to sue in respect of defamatory matters which can be seen as having a tendency to damage it in the way of its business. ${ }^{34}$

Despite the historic roots of a company's right to sue in defamation, during the debates leading to the introduction of the Defamation Act 2013, the fact that corporations were able to do so to protect their reputations was a controversial issue. Indeed, according to Mullis and Scott 'preventing corporates from suing [was] a primary goal of some libel reformers' ${ }^{35}$ This is reflected by a Ministry of Justice consultation on the Bill, in which there was significant support for the idea that English defamation law should follow the 2005 Australian uniform defamation reforms ${ }^{36}$ which, pursuant to sec 9 of the Defamation Act

\footnotetext{
28 [1894] 1 Queen's Bench (QB) 133.

${ }^{29}$ Ibid. 141 (Lopez LJ), 148 (Kay LJ).

${ }^{30}$ Ibid. 138.

${ }^{31}$ [1964] AC 234.

${ }^{32}$ Ibid. 262.

${ }^{33}$ [1992] QB 770.

${ }^{34}$ Ibid. 546.

${ }^{35}$ A Mullis/A Scott, The Swing of the Pendulum: Reputation, Expression and the Re-Centring of English Libel Law (2012) 63 Northern Ireland Legal Quarterly (NILQ) 27, 54.

${ }^{36}$ Ministry of Justice, Draft Defamation Bill: Summary of Responses to Consultation (CP(R) 3/11, 2011), para15.
} 
2005, had removed the right to sue for defamation from companies with ten or more employees. ${ }^{37}$ However, due to the UK being a signatory to the ECHR, the options for reform available to Parliament were limited as compared to those available to Australian legislators ${ }^{38}$ Indeed, the Joint Committee on the Draft Defamation Bill heard evidence that removing the right to sue in defamation from companies might be incompatible with the ECHR.${ }^{39}$ Consequently, rather than following the Australian example, the day before the 2013 Act received Royal Assent, Parliament introduced a qualification for the sec 1(1) serious harm requirement for bodies trading-for-profit; to meet the serious harm threshold, under sec 1(2), they need to demonstrate actual or likely serious financial loss. Although included late, this qualification was enshrined within the Act.

However, subsequent to the introduction of the 2013 Act in the UK, the New South Wales (NSW) government has undertaken a statutory review of the Defamation Act $2005^{40}$ that has clearly recognised the importance of corporate reputation and has left open the possibility of reform in that area. Although the Review held that the balance struck by sec 9 continues to be appropriate, it was persuaded to recommend a further discrete review of the provision to determine whether or not it should be amended. ${ }^{41}$ Its decision was based on two factors: firstly, the fact that Australia's approach does not correspond with the approaches in

\footnotetext{
${ }^{37}$ Defamation Act 2005 (NSW, Qld, Vic, SA, Tas) sec 9; Defamation Act 2006 (NT) sec 9; Civil Law (Wrongs) Act 2002 (ACT) sec 121. For analysis of the impact of these reforms on corporations see generally: $M$ Collins, Protecting Corporate Reputations in the Era of Uniform National Defamation Laws (2008) 13 Media \& Arts Law Review (MALR) 447.

${ }^{38}$ Acheson (2018) $10 \mathrm{JML} 49,49 \mathrm{f}$.

${ }^{39}$ Joint Committee on the Draft Defamation Bill, Oral and Associated Written Evidence Volume II (2010-12, HL 203, HC 930-II) 18-19 (Lord Lester), 381-386 (Lord McNally).

${ }^{40}$ New South Wales Government, Statutory Review Defamation Act 2005, June 2018.

${ }^{41}$ Ibid. Para 2.10 and Recommendation 2.
} 
other similar jurisdictions, ${ }^{42}$ including the United States ${ }^{43}$ Canada, ${ }^{44}$ New Zealand ${ }^{45}$ and the UK; secondly, the submission from the NSW Bar Association, which clearly reflects the arguments advanced throughout this article, that sec 9 should be expanded to permit all corporations to sue for defamation, on the basis that the reputations of businesses are also critically important, and are a legitimate interest, that needs to be protected. ${ }^{46}$

Since the coming into force of the 2013 Act the ECtHR has left open the possibility that corporations could claim an ECHR right to reputation under the A1P1 right to property. As stated in section I, in his article Acheson argues that corporations should not have a right to reputation under A1P1, but rather should have such a right under art 8 ECHR. ${ }^{47}$ Arguably, this controversy is fuelled by the problematic precondition that defamation actions by corporations are dependent upon those companies having a reputation that can be damaged as, Oster states, reputation is, 'at first glance', a characteristic attributed to individuals. ${ }^{48}$ However, as established in section II, companies can also have a reputation. As argued in section II, and as recognised by the NSW Government's Review of the Australian Defamation Act 2005, in many situations a company's reputation is vital, not only for its prosperity, but also its very existence The 'health' of a company's reputation can directly affect the overall state of the business which, in turn, can have a significant impact on the local community in which it is based. Therefore, it has the potential to indirectly affect many

\footnotetext{
${ }^{42}$ Ibid. Para 2.7.

${ }^{43}$ Ibid. The Review recognises that 'in most states of the United States, a corporation can sue in defamation where an untrue "actionable statement" has been made in writing or verbally to a third person, and has caused the corporation damage.'

${ }^{44}$ Canada allows corporations to sue in defamation in the same way as natural persons, although some Canadian academics have suggested that Canada follow the Australian approach, citing corporations' disproportionate resource and influence as compared to individuals having a potentially chilling effect on free speech.

${ }^{45}$ Section 6 of the Defamation Act 1992 allows a body corporate to bring a claim for defamation where the defamatory publication has, or is likely to, cause the body corporate a pecuniary loss.

${ }^{46}$ New South Wales Government, Statutory Review Defamation Act 2005, June 2018, para 2.4.

${ }^{47}$ Acheson (2018) 10 JML 49.

${ }^{48} \mathrm{~J}$ Oster, The Criticism of Trading Corporations and their Right to Sue for Defamation (2011) 2 Journal of European Tort Law (JETL) 255, 258.
} 
individuals. As a result, it is arguable that the reputation of businesses is at least as important as the reputation of individuals. Thus, this article disagrees with Acheson's view, and instead argues that the right to reputation should be subsumed within the concept of reputation as property and should, therefore, enable corporations to avail themselves of a positive right to the protection of reputation, as property, under A1P1.

\section{The notion of reputation as property?}

In determining the issue of whether corporate reputation can amount to 'property', the inevitable question begged is what in fact is 'property'; what are its defining characteristics and features as a legal institution? This question is not easy to answer and is one that has challenged legal scholars for many years. Indeed, various theories have emerged over time to try to explain the nature of property as an institution. Perhaps, however, a simple starting point is to remind ourselves of the traditional categorisation of property in English law, namely, that property falls into the camps of either Real Property, Chattels-Real (leases) and Personalty (this category being further sub-divided into Choses in Possession (such as money and chattels) and Choses in Action (such as Copyright, Patents and shares etcetera).

In his 'The Second Treatise of Government' it was John Locke who proposed a theory of private property rights. Locke rooted this in the law of nature, which, he claimed, permitted individuals to appropriate and exercise control rights over things in the world like land and other material resources. ${ }^{49}$ Thus, it was Locke who provides us with one of the original justificatory accounts about the legitimacy of private property rights. Yet, it was the philosopher Jeremey Bentham who had to remind lawyers that property is not a thing but

\footnotetext{
${ }^{49} J$ Locke The Second Treatise of Civil Government 1690 ch 2.
} 
rather a relationship, property being the condition of being 'proper' that is 'belonging' to a particular person. As a result, it is the relationship between the thing ('object') and the person ('subject') which provides us with the key to understanding the concept of property. ${ }^{50}$ Yet it is rather simplistic to think just in terms of there being an owner of property in terms of a thing, for the reality is more complex, due to the fact that it is often possible for conflicting claims to be brought by two or more 'subjects' in respect of the same 'object', and legal systems frequently have to deal with the merits of relative claims. Thus, land, for example, as an object of property, may generate a variety of respective claims simultaneously made by, for example, an owner-occupier, leaseholder, mortgagee or neighbour. Consequently, at its heart, in terms of orthodox property law theory, property law systems often have to resolve the different claims brought by the subjects of property as against the object of property. ${ }^{51}$

A powerful and salient feature of the property concept is the fact that it represents a dynamic relationship between subject and object, heavily influenced by social, political and economic factors at any given time. The 'subjects' of property can change. For example, for many years, married women could not own property in their own right with all their property vesting in their husbands upon marriage. ${ }^{52}$ Similarly, and more importantly for the purposes of this paper, it is significant that the 'objects' of property are susceptible to change, that is, the 'resources' capable of lying at the heart of the institution of property. A clear single example here can be gleaned from the fact that a few hundred years ago slaves were regarded as the 'objects' of property, an idea which nowadays would seem ridiculous as well as outrageous. The point here being that the objects of property clearly change with the political

\footnotetext{
${ }^{50} \mathrm{~J}$ Bentham, An Introduction to the Principles of Morals and Legislation $(1789,1948) 337$ note 1 (chap XVI, sec 26).

${ }^{51}$ See generally: CR Noyes, The Institution of Property (1936) 357 and KJ Gray/ PD Symes, Real Property and Real People (1981) ch 1.

52 This position was changed to favour married women by virtue of the introduction of the Married Women's Property Acts 1870 and 1882 and the Law Reform (Married Women and Tortfeasors) Act 1935.
} 
and socio-economic development of society. It is this dynamic quality of the institution of property, in particular its changing objects, which plays a vital role in our understanding of the institution of property. The objects of property are therefore clearly susceptible to change as a result of the socio-economic and political forces which are at work in society at any given time. Indeed, in the words of Clarke and Kohler.: ${ }^{53}$

...property is no more than a normative set of relationships which might be attached to whatever subject-matter society deems it necessary or beneficial to make the subject of property...

In this connection it can be noted that there is often a pressure in society to recognise new property rights. So, for example, in his article 'The New Property', Reich argued that new forms of wealth (such as welfare benefits), which have arisen in the wake of the increased role of government, demand the same legal protection as that accorded to private property. ${ }^{54}$ Reich argued this so as to entrench welfare payments in order to bring them within the constitutional safeguard of preventing 'deprivation of property without due process of law', whilst using the rhetorical power of private property. However, despite this effort, as Clarke and Kohler point out, ultimately the term 'property' is simply a means of signposting what is and what is not regarded as a resource. ${ }^{55}$ This is necessarily a political and socioeconomic question and one which helps dictate the changing nature of the objects of property. Whether or not one agrees with it as a philosophy, the reality is, nowadays, we live in a world where neo-liberal economics has become the orthodoxy bringing with it its new vision of property - a vision that implies the private appropriation of virtually all value. ${ }^{56}$ Therefore, against this important backdrop it surely then becomes arguable that the 'objects'

\footnotetext{
${ }^{53}$ A Clarke/P Kohler, Property Law Commentary and Materials, Law in Context Series (2005), 372. The word 'subject' is what we have termed object in this part of this paper.

${ }^{54} R$ Reich, The New Property (1964) 5 Yale Law Journal (YLR) 733.

${ }^{55}$ Ibid at 374.

${ }^{56}$ G Dinwoodie/M Janis, Trademark Law and Theory, A Handbook of Contemporary Research (2008) ch 1.
} 
of property can be seen as capable of changing so as to incorporate the concept of corporate reputation - clearly a thing of value in the market place.

It can be pointed out that trademarks are signs of authorship of certain products which carry with them the reputation of the author. This reputation, like corporate goodwill, is a thing which is earned in the market place and generates value in the form of the trader's goodwill. ${ }^{57}$ It was, however, in Victorian times that actions relating to trademark violation came to be seen as primarily actions founded in the protection of a property interest rather than an action based on the prevention of fraud. ${ }^{58}$ However, as has been noted, the adoption of the language of property as regards trademarks in the Victorian period and early 20th century case law may have had little impact because it was recognised that the 'property' label was just that, a label. A label used to solve a particular problem, namely, that of explaining Equity's extended jurisdiction beyond that of the Common Law and the availability of injunctive relief. Adoption of that label did not in itself mean that trademarks were property like land or goods or even like copyright or patents. In this vein in Leather Cloth Co v American Leather Cloth ${ }^{59}$ Lord Cranworth indicated that the term property was used in the context of trademarks in 'a sense very different from what is meant by it when applied to a house or watch'. This seems to suggest that it is arguable that trademarks are at worst a form of quasi-property, as can be argued is confidential information. ${ }^{60}$ If this is right why should corporate reputation not similarly, at the very least, qualify as quasi-property in this sense? Corporate reputation is something that is earned in the marketplace; it might go up

\footnotetext{
${ }^{57}$ See: Spalding v Gamage (1915) 32 RPC 273 per Lord Parker.

${ }^{58}$ See generally: Dinwoodie/Janis (fn 56) ch 1.

59 (1865) 11 HLC 523, 533.

${ }^{60}$ As Gummow $\mathbf{J}$ stated when considering the proprietary quality of confidential information in Breen $v$ Williams (1995-6) 186 CLR 71 at 129, 'it [is not] acceptable to argue that because in some circumstances, the restraint of an apprehended or continued breach of confidence may involve enjoining third parties...it follows that the plaintiff who asserts an obligation of confidence therefore has proprietary rights in the information in question which, in turn found a new species of legal right'.
} 
or down depending on circumstances. ${ }^{61}$ It is something which is exclusive to a business and which is capable of assignment to any purchaser of the business. It can also be brought to an end upon the dissolution of a company. Unlike the freehold title to a house or a watch it lacks certainty but at the same time it does have value as it is something earned in the marketplace, through labour and endeavour, rather like the goodwill represented in a trademark. It is an asset to a business and it is submitted has enough proprietary quality to it to at least be treated as a form of quasi-property. If Robert Reich felt able to use the rhetoric of property to argue welfare payments were a form of property for the purposes of safeguarding the same within the US Constitution, why can we not similarly use the rhetoric of property to argue for the protection of corporate reputation for the purposes of the European Convention on Human Rights Article 1 First Protocol?

However, against the backdrop of the modern world of neo-liberal economics, and its implied conception of property, namely, the private appropriation of all value, it may, in fact, be more appropriate to take the altogether bigger, and perhaps logical step, of treating corporate reputation as 'property' in the fullest sense. It is submitted that this is the approach of Robert Post. Arguably his 'social foundations' of reputation, ${ }^{62}$ which have filtered into the law of defamation, ${ }^{63}$ serve to support this notion of reputation as property (as opposed to reputation being categorised as quasi-property). Post's foundations include dignity, honour and property. Reputation as dignity is not applicable to corporations. ${ }^{64}$ As Lord Hoffmann

\footnotetext{
${ }^{61}$ For example, we can note here the overnight destruction of the corporate reputation of Townsend Thoresen after the Herald of Free Enterprise ferry disaster of 1986, just prior to the takeover by the company P \& O European Ferries Plc.

${ }^{62} R$ Post, The Social Foundations of Defamation Law: Reputation and the Constitution (1986) 74 California Law Review (Cal L Rev) 691.

${ }^{63}$ Coe (2015) JBL (4) 313, 315-319; See generally: G Chan, Corporate Defamation: Reputation, Rights and Remedies (2013) 33 Legal Studies (LS) 268.

${ }^{64}$ Post (1986) 74 Cal L Rev 313, 707-721.
} 
said in Jameel, a corporation has no soul ${ }^{65}$ and, therefore, cannot feel any loss of dignity. ${ }^{66}$ Thus, this concept only applies to the reputation of a natural person. However, Post's concepts of reputation as honour and reputation as property are potentially applicable to corporate defamation. In respect of the former, this has already been the subject of considerable academic attention, and, as a result, is beyond the scope of this article. ${ }^{67}$ Rather, because of the lack of clarity emanating from recent case law, ${ }^{68}$ this article is concerned with the latter's ability to provide a conceptual basis for corporations to sue in defamation.

According to Post, there are: '... aspects of modern defamation law that can be understood only by reference to the concept of reputation as property, as, for example, the fact that corporations and other inanimate entities can sue for defamation. ${ }^{99}$ Post's thesis that reputation as property provides a conceptual foundation for companies to sue in defamation corresponds with Oster's view, who has argued that 'it is a distinctive feature of a company's suit for defamation that it may exclusively ${ }^{70}$ be explained by the conception of reputation as property. ${ }^{, 71}$ Indeed, in The Metropolitan Saloon Omnibus Company (Limited) v Hawkins ${ }^{72}$ Pollock CB stated that: 'it would be very odd if a corporation had no means of protecting itself against wrong; and, if its property is injured by slander, it has no means of redress

\footnotetext{
65 [2007] 1 AC 359, para 91.

${ }^{66}$ See also, McDonald's Corporation v Steel and Morris [1999] EWCA Civ 1144; Hays plc v Jonathan Hartley [2010] EWHC 1068, para 24.

${ }^{67}$ See generally Coe (2015) 4 JBL 313; Coe (2013) 18 Comms Law 112; Chan (2013) 33 LR 268; Oster (2011)

2 JETL 255, 278.

${ }^{68}$ See section VI below.

${ }^{69}$ Post (1986) 74 Cal L Rev, 693, 696. See also: Oster (2011) 2 JETL 255, 278.

70 Oster is of the view that reputation as property is the only social foundation of reputation that applies to corporations. However, this is subject to academic debate that, although is beyond the scope of this article, presents an opportunity for further detailed enquiry. For example, Peter Coe has argued that reputation as honour is equally applicable. See generally Coe (2015) 4 JBL 313, 313; Coe (2013) 18 Comms Law 112. To the contrary, see: Martin Marietta Corp v Evening Star Newspaper Co 417 Federal Supplement (F Supp) 947, 955 (DDC 1976); Derbyshire County Council v Times Newspapers Ltd [1993] AC 534, 544; Dikoko v Mokhatla 2006 (6) South African Law Reports (SA) 235 (CC) para 109 (Sachs J); D Milo, Defamation and Freedom of Speech (2008), 28; E Barendt, What is the Point of Libel Law? (1999) 52 Current Legal Problems (CLP) 111, 115.

${ }^{71}$ Oster (2011) 2 JETL 255, 259.

72 (1859) 4 Hurlstone \& Norman Exchequer Reports (H\&N) 87.
} 
except by action. ${ }^{73}$ Thus, the value of reputation is determined by the market in the same way as any property loss is measured. ${ }^{74}$ As Milo suggests, the notion of reputation as property reflects the image of the market society; individuals, he argues, are connected through the institution of the market. ${ }^{75}$ Accordingly, Post advances the argument that the concept of reputation as property is reputation in the marketplace; a notion of reputation that: 'can be understood as a form of intangible property akin to goodwill...acquired as result of an individual's efforts and labour. ${ }^{, 76}$ Hence, if reputation is injured, the resulting loss is financially quantifiable. ${ }^{77}$

In conclusion, it is submitted that Post's notion of reputation as property provides strong conceptual foundations for reputation to be protected as an aspect of property in the fullest sense. At the very least, corporate reputation, as a market generated 'asset', has enough modern-day 'proprietary characteristics' to qualify as a form of quasi-property. However, as will be discussed in section VI, despite these contentions, that reputation as property provides a legitimate conceptual foundation for corporations to sue in defamation, the existence of a positive right to reputation as property for bodies that trade for profit pursuant to A1P1 is, by virtue of equivocal jurisprudence from the ECtHR, unclear. In turn, this has led to confusion in English law. Before considering the Strasbourg Court's case law, and the effect this has had on English jurisprudence, the following section will look at how companies have sought to protect their reputations via the application of art $10 \mathrm{ECHR}$, and why this is not ideal.

\footnotetext{
${ }^{73}$ Ibid at 90.

${ }^{74}$ Oster (2011) 2 JETL 255, 259; Milo (fn 70) 27.

${ }^{75}$ Milo ibid.

${ }^{76}$ Post (1986) 74 Cal L Rev 691, 693. See also: V Veeder, The History and Theory of the Law of Defamation 4 Columbia Law Review (Col L R) (1904) 546.

${ }^{77}$ Milo (fn 70) 27.
} 


\section{Article 10 ECHR}

Article 10(1) provides for the right to freedom of expression. Article 10(2) qualifies this right by providing that its application can be restricted for, inter alia, 'the protection of the reputation... of others.' As this is the only explicit mention of reputation in the ECHR, historically, the Strasbourg Court has treated reputation as relevant to it only in the context of the application of art 10(2). ${ }^{78}$

It is clear from the jurisprudence of the ECtHR that, in addition to individual reputation, the protection of corporate reputation is a justifiable reason to restrict free speech pursuant to art 10(2). In other words, art 10(2) allows Member States to restrict freedom of expression to protect corporate reputation. This is illustrated by Steel and Morris $v$ United Kingdom ${ }^{79}$ in which the Strasbourg Court held that 'the English law of defamation, and its application in this particular case, pursued the legitimate aim of "the protection of the reputation or rights of others." ${ }^{80}$ However, as explained in the following sections, legitimately restricting the right to freedom of expression in order to protect a countervailing interest, such as reputation, does not provide the same level of protection as guaranteeing that interest substantive positive ECHR protection in its own right, ${ }^{81}$ as would be the case pursuant to an A1P1 right to reputation as property.

\footnotetext{
${ }^{78}$ For example, see: Lingens v Austria [1986] ECHR 7; Acheson JML (2018) 10 JML 49, 53; S Smet, Freedom of Expression and the Right to Reputation: Human Rights in Conflict (2010) 26 American University International Law Review ( AUILR) 183, 192.

79 [2005] ECHR 103. The ECtHR judgment represented the end of the 'McLibel' litigation that involved defamation proceedings brought by the McDonald's corporation against two environmental activists: McDonald's Corp v Steel (No 1) [1995] 3 All ER 615.

${ }^{80}$ Ibid para 86; See also: Uj v Hungary App No 23954/10 (ECtHR, 19 ${ }^{\text {th }}$ July 2011) para 22; Kuliś and Różycki v Poland App No 27209/03 (ECtHR, 6 October 2009) para 35; Markt Intern Verlag GmbH v Germany (1190) 12 EHRR 161, paras 34-35.

${ }^{81}$ H Fenwick/ G Phillipson, Media Freedom under the Human Rights Act (2006) 1070; Oster (2011) 2 JETL 255, 263; Acheson 10 (2018) JML 49, 54 f.
} 
In his article, Acheson, very usefully, sets out three reasons why this distinction between corporate reputation being protected by a positive Convention right, as opposed to being merely a permissible justification for restricting free speech, is important. ${ }^{82}$ Those reasons are: (i) this 'status' will affect the level of protection afforded to corporate reputation in English defamation law; (ii) if companies were subject to a positive ECHR right to reputation, then Member States would be obliged to protect that right; and (iii) if a Convention right to corporate reputation existed then companies could apply to the ECtHR alleging a violation of that right by a Member State. By drawing on Acheson's article, the remainder of this section will consider their implications.

\section{A Impact on English defamation law}

Corporate claimants' reputation would be subject to a greater level of protection in English defamation proceedings if that interest were to fall within the ambit of a positive ECHR right than if it did not. Indeed, although relating to the link between art 8 and individual reputation, this hierarchy of protection was explicitly recognised by the ECtHR in Lindon v France: ${ }^{83}$

Accepting that respect for reputation is an autonomous human right, which derives its source from the Convention itself, leads inevitably to a more effective protection of the reputation of individuals vis-á-vis freedom of expression.

Thus, if a positive Convention right to corporate reputation exists then it would also be subject to this 'more effective protection' from the ECtHR, and in English defamation law. Applying this to the existence of an A1P1 right to reputation as property, the permissibility of

\footnotetext{
${ }^{82}$ Ibid 54-59.

83 [2007] ECHR 836.
} 
an interference with the Article would depend on its proportionality, ${ }^{84}$ which, according to the ECtHR in Appleby $v U K,{ }^{85}$ involves 'balancing the rights in issue' ${ }^{86}$ when the right to property conflicts with the art 10(1) right to free speech. Although protection for property rights is, arguably, less extensive than for other fundamental rights, ${ }^{87}$ and restrictions on A1P1 rights 'attract a particularly wide margin of appreciation, ${ }^{88}$ it is likely that corporate reputation would be subject to greater protection if it falls within the scope of A1P1 than if it is not subject to positive protection by a Convention right. ${ }^{89}$

Conversely, if corporate reputation is not subject to a positive Convention right then the reputational interests in a company's defamation claim are relevant only as a justification for restricting the defendant's expression under art 10(2), as opposed to positively protecting the claimant's reputation. ${ }^{90}$ As demonstrated by the jurisprudence of the Strasbourg Court, Member States must meet a high threshold in order to comply with art 10(2) and, consequently, for a company's reputation to be protected via a legitimate and justifiable restriction of the defendant's art 10(1) free speech right. According to the ECtHR's judgment in Sunday Times v UK (No 2), pursuant to art 10(2), any restriction of freedom of expression must be 'necessary in a democratic society' in that it deals with a 'pressing social need' and is 'proportionate to the legitimate aim pursued.' ${ }^{91}$ The Court went on to say that if the restriction of the art 10(1) right is challenged in Strasbourg then its necessity 'must be convincingly established' by the Member State. ${ }^{92}$ Furthermore, corporate defamation claims

\footnotetext{
${ }^{84}$ Pressos Compania Naviera Sav Belgium [1995] ECHR 471 para 38.

85 [2003] ECHR 222.

${ }^{86}$ Ibid para 49.

${ }^{87}$ E Barendt, Freedom of Speech (2nd edn 2005) 254.

${ }^{88}$ H Fenwick/ G Phillipson, Media Freedom under the Human Rights Act (2006) 147; $R$ (Countryside Alliance) $v$ Attorney General [2007] UKHL 52, para129.

${ }^{89}$ Acheson (2018) 10 JML 49, 56.

${ }^{90}$ Ibid at 54.

91 [1991] ECHR 50, para 50.

${ }^{92}$ Ibid.
} 
often involve matters of public interest. ${ }^{93}$ The Court's jurisprudence is clear that where the public interest is at stake this threshold is raised to an even higher level. It has stated that any potential protection afforded to companies' reputational interests via an art 10(2) restriction on free speech is subject to the 'most careful scrutiny' and in Heinisch v Germany ${ }^{94}$ it held that art 10(2) provides 'little scope...for restrictions on debate on questions of public interest. ${ }^{95}$ Accordingly, Oster, Acheson and Mullis and Scott have all observed that if the protection of reputation is treated solely as a justification for restricting the defendant's art 10(1) right to freedom of expression, then the Strasbourg Court's human rights analysis will start from the presumption that their free speech rights take priority over the countervailing reputational interests of the claimant company. ${ }^{96}$

\section{B Obligation on member states to protect corporate reputation}

If a positive ECHR right to corporate reputation existed, then, crucially, it would give rise to duties and obligations that would be imposed on Member States in respect of its protection. Conversely, without such a right, the protection of corporate reputation within UK law is merely permissible, rather than being required. ${ }^{97}$

This distinction is illustrated by evidence given by Lord McNally to the Joint Committee on the Draft Defamation Bill ${ }^{98}$ on the interpretation of the ECtHR's judgment in Steel and Morris $v$ United Kingdom ${ }^{99}$ in which the Court held that a Member State 'enjoys a

\footnotetext{
${ }^{93}$ For example, see: Jameel $v$ Wall Street Journal Europe Sprl [2006] UKHL 44, para 185; J Oster, Media Freedom as a Fundamental Right (2015), 157.

94 [2011] ECHR 1175.

95 Ibid para 66.

96 Oster (2011) 2 JETL 255, 263; A Mullis/ A Scott (2012) 63 NILQ 27, 34; Acheson (2018) 10 JML 49, 55.

${ }^{97}$ D Howarth, Libel: Its Purpose and Reform (2011) 74 Modern Law Review (MLR) 845, 874; Oster ibid at 264.

${ }^{98}$ Joint Committee on the Draft Defamation Bill, Oral and Associated Written Evidence Volume II (2010-2012, HL 203, HC 930-II). 99 [2005] ECHR 103.
} 
margin of appreciation as to the means it provides under domestic law to enable a company to challenge the truth, and limit the damage, of allegations which risk harming its reputation. ${ }^{100}$ The Court went on to determine that: '[i]f...a State decides to provide such a remedy to a corporate body' then defendants' art 10 rights require 'a measure of procedural fairness' in the operation of that remedy. ${ }^{101}$ According to Lord McNally this could be interpreted as ruling that the Member State's margin of appreciation 'extends as far as deciding to offer no remedy.' ${ }^{102}$ As Acheson states, this interpretation must be correct as art 1 ECHR places a requirement on Member States to 'secure to everyone within their jurisdiction the rights and freedoms defined in...this Convention,' whereas there is no obligation to protect interests not falling within the scope of a Convention right.

Thus, if corporate reputation falls within the scope of a Convention right, then it will give rise to obligations under art $1 .{ }^{103}$ As explained above, these can include: (i) negative obligations, which prohibit Member States from action which would violate ECHR rights; and (ii) positive obligations, in that Members States must ensure the protection of the right in the context of private law, such as defamation claims. ${ }^{104}$ Consequently, as discussed further in section VII, if the UK is under a positive obligation to protect corporate reputation, removing the right of companies to sue in defamation, as happened, to an extent, in Australia, is likely to be incompatible with the ECHR, and hence would be prevented.

\section{The right of companies to apply to the European Court of Human Rights}

\footnotetext{
${ }^{100}$ Ibid para 94.

101 Ibid para 95.

102 Joint Committee (fn 98) 385.

103 Acheson (2018) 10 JML 49, 58.

${ }^{104}$ Von Hannover v Germany (No 1) [20044] ECHR 294; Oster (2011) 2 JETL 255, 264. As Acheson states 'positive' obligations are those that require [Member States] to take actions to ensure the enjoyment of Convention rights’ ibid. See also: Gul v Switzerland [1996] ECHR 5 para $7 .$.
} 
According to Emberland, for the purposes of art 34 ECHR, corporations, including for-profit companies, are classed as 'non-governmental organisations', meaning they have locus standi to apply to the ECtHR where it is claimed that their rights have been violated. ${ }^{105}$

Consequently, if a positive ECHR right to corporate reputation existed then it would provide a mechanism for companies to apply to the Strasbourg Court when a violation of that right is alleged. ${ }^{106}$

\section{VI 'Goodwill' and the scope of Article 1 Protocol 1 of the ECHR}

Pursuant to the previous section, it is clear that the existence or otherwise of a positive ECHR right to corporate reputation has important repercussions for the ongoing application, and any future reform, of English defamation law. ${ }^{107}$ However, as will be discussed in this section, whether or not such a right exists within the scope of A1P1 is unclear which, in turn, has serious implications for claimants trading for profit within an English law context.

As a general rule, the ECtHR has 'never doubted' that corporations can be beneficiaries of ECHR rights, ${ }^{108}$ as, by definition, companies are 'rights bearing legal entities ${ }^{109}$ which, without enforceable rights, would be unable to pursue and fulfil the object(s) of their existence. ${ }^{110}$ As Acheson states: 'The existence of corporate rights under a supranational treaty such as the ECHR has the benefits of promoting some uniformity across jurisdictions, and of protecting those rights against the arbitrary use of state power. ${ }^{111}$ Case

\footnotetext{
${ }^{105}$ M Emberland, The Human Rights of Companies: Exploring the Structure of ECHR Protection (2006) 4.

${ }^{106}$ E Barendt et al, Media Law: Text, Cases and Materials (2014) 366; G Millar, Whither the Spirit of Lingens? (2009) 3 European Human Rights Law Review (EHRLR) 277, 282.

107 Acheson (2018) 10 JML 49, 58.

${ }^{108}$ M Emberland, The Human Rights of Companies: Exploring the Structure of ECHR Protection (2006) 4.

109 J Bishop, The Limits of Corporate Rights Obligations and the Rights of For-Profit Corporations (2012) 22 Business Ethics Quarterly (BEQ) 119,128.

${ }^{110}$ Acheson (2018) 10 JML 49, 51.

${ }^{111}$ Ibid.
} 
law such as Sunday Times $v U K\left(\right.$ No 2), ${ }^{112}$ Autronic AG $v$ Switzerland ${ }^{113}$ and Bladet Troms $\phi v$ Norway ${ }^{114}$ demonstrates that some of the ECtHR's most important and influential free speech jurisprudence emanates from claims brought by corporations.

However, the Strasbourg Court's position relating to corporations' right to reputation as property under A1P1 is far from clear. Underlying this lack of clarity in the Court's thinking is the conflict between two principles found in its jurisprudence. ${ }^{115}$ On the one hand, A1P1 applies only to existing possessions and, therefore, does not guarantee the right to acquire possessions. On the other hand, it has been established that actions that diminish the present value of a professional's 'clientele' or a corporation's 'goodwill' may amount to an interference with a possession, and therefore the right to reputation as property, for the purposes of A1P1. ${ }^{116}$ For a number of years the former principle did not, to any great extent, constrain the application of the latter. ${ }^{117}$ However, as will be seen in the following section, the Strasbourg Court, and to a lesser extent, the ECHR, has not only left open the applicability of A1P1 to corporate reputation, but has created two conflicting lines of case law. The first recognises that the 'goodwill' of a business is a possession under A1P1, therefore attracting the protection the article. To the contrary, the second line of jurisprudence establishes that reductions in goodwill due to reductions in expected future income are effectively claims for loss of future income, which does not attract the protection of A1P1.

\section{A A1P1 and the equivocal position of the European Court of Human Rights}

A1P1 provides that:

\footnotetext{
112 [1991] ECHR 50.

113 [1990] ECHR 12.

114 [1999] ECHR 29.

115 This is discussed in the following paragraphs.

${ }^{116}$ A Bhasin, Future Income Versus Goodwill under A1P1 - A Distinction without a Difference? (2012) 17 Judicial Review (JR) 226, 226.

117 Ibid.
} 
'Every natural or legal person is entitled to the peaceful enjoyment of his possessions. No one shall be deprived of his possessions except in the public interest and subject to the conditions provided for by law and by the general principles of international law.'

\section{B Goodwill as a possession under A1P1}

The goodwill of a business as a possession has historic roots. For example, in Trego v Hunt ${ }^{118}$ Lord Macnaghten stated that goodwill 'is the whole advantage, whatever it may be, of the reputation and connection of the firm. ${ }^{, 19}$ From a Strasbourg perspective it can be traced back to König v Germany ${ }^{120}$ from which Judge Wiarda's opinion that ' $[\mathrm{t}]$ he clinic, the practice and the patients represented an element of "goodwill" which likewise was in the nature of a private right similar, in some respects, to the right of property' was relied upon by the applicants in Van Marle $v$ Netherlands ${ }^{121}$ which represented the first case on the protection of goodwill under A1P1. The applicants complained of a state action that they alleged had caused a decrease in 'the value of the goodwill of their accountancy practices.' 122 The ECtHR held that:

...by dint of their own work, the applicants had built up a clientele; this had in many respects the nature of a private right and constituted an asset and, hence, a possession within the meaning of the first sentence of $[\mathrm{A} 1 \mathrm{P} 1] \ldots$

The refusal to register the applicants...radically affected the conditions of their professional activities and the scope of those activities was reduced. Their income fell, as

\footnotetext{
118 [1896] AC 7 (HL).

119 Ibid at 24.

${ }^{120}$ App No 6232/73 (1979-80) 2 EHRR 170.

${ }^{121}$ App Nos 8543, 8674, 8675 and 8685/79 (1986) 8 EHRR 483, para 63.

122 Ibid at para 39 .
} 
did the value of their clientele and, more generally, their business. Consequently, there was an interference with their right to peaceful enjoyment of their possessions. ${ }^{123}$

The Strasbourg Court's approach in Van Marle was subsequently adopted in a number of cases, ${ }^{124}$ giving rise to a consistent line of case law that determines that the goodwill of a professional practice, ${ }^{125}$ or of a 'business engaged in commerce', ${ }^{126}$ can be a possession. Moreover, in Mowbray's view, the case of Tre Traktörer Aktiebolag v Sweden ${ }^{127}$ indicates that A1P1 can protect 'non-material commercial interests such as the goodwill (that is, the financial value of a company's reputation) of established businesses. ${ }^{128}$ Consequently, as Oster states, the interest in corporate reputation 'neatly fits' with this jurisprudence and should, therefore, be protected under A1P1.${ }^{129}$ However, despite this, as set out in the following section, a diverging, and conflicting line of case law has emerged which casts doubt on whether A1P1 offers positive protection for corporation reputation.

\section{Conflicting lines of case law from the European Commission on Human Rights and the European Court of Human Rights}

Despite the ECtHR's jurisprudence clearly identifying goodwill as a possession under A1P1 a separate line of case law has established the principle that a loss of future income will not

\footnotetext{
${ }^{123}$ Ibid. at paras 41-42.

${ }^{124}$ For example, see: Karni $v$ Sweden (App No 11540/85), 8 March 1988; Tre Traktörer Aktiebolag $v$ Sweden (App No 10873/84) (1991) 13 EHRR 309 para 54 f; Fredin v Sweden (No 1) (App No 12033/86) (1991) 13 EHRR 784; Pinnacle Meat Processors v United Kingdom (App No 33298/96), 21 October 1998; Iatridis $v$ Greece (App No 31107/96) (2000) 30 EHRR 97; Olbertz v Germany (App No 37592/97), 25 May 1999.

${ }^{125}$ Van Marle v Netherlands App Nos 8543, 8674, 8675 and 8685/79 (1986) 8 EHRR 483.

${ }^{126}$ Malik v United Kingdom [2012] ECHR 438, [93]; Denimark Ltd v United Kingdom (2000) 30 EHRR CD144, 150.

127 (App No 10873/84) (1991) 13 EHRR 309 para 53. The Court found that A1P1 was engaged by the withdrawal from a restaurant of its licence to serve alcohol because of the 'adverse effects of the goodwill and value of the restaurant' caused by that withdrawal.

${ }^{128}$ A Mowbray, Cases and Materials on the European Convention on Human Rights (2nd edn 2007) 906.

${ }^{129}$ Oster (2011) 2 JETL 255, 263. See also: Chan (2013) 33 LS 268, 269.
} 
engage the article, as it does not protect the right to acquire property. For instance, in Marckx $v$ Belgium ${ }^{130}$ the Court held that A1P1 'does no more than enshrine the right of everyone to the peaceful enjoyment of "his" possessions...consequently it applies only to a person's existing possession and...it does not guarantee the right to acquire possession... ${ }^{131}$ Similarly, in JA Pye (Oxford) Ltd $v U K^{132}$ the Strasbourg Court found that A1P1 'does not...guarantee the right to acquire property., 133

To confuse matters further, shortly after Marckx, the Commission handed down its judgment in $X v$ Germany, ${ }^{134}$ which, in a number of cases, was subsequently cited as authority for the proposition that 'future income could only be considered to constitute a "possession", if it had already been earned or where an unenforceable claim existed to it., 135 However, although an identical formulation of the $X$ proposition appeared in Pinnacle Meat Processors $v$ United Kingdom, ${ }^{136}$ the Commission did not acknowledge any inconsistency between the proposition and the fact that the 'applicants' valuation of their businesses include substantial elements represented by future income. ${ }^{137}$ As acknowledged by Bhasin, the judgments in the Van Marle line of case law discussed in the previous section did not refer to the $X$ proposition at all, despite them being handed down after $X$ was decided. ${ }^{138}$ This inconsistency and lack of clarity, even within the Commission's own jurisprudence, is further demonstrated by the fact that the Admissibility Decision in Karni v Sweden ${ }^{139}$ - which is one

\footnotetext{
130 (App No 6833/74) (1979) EHRR 330. The case concerned an illegitimate child's ability to inherit or receive inter vivos gifts from her mother,

${ }^{131}$ Ibid para 50.

132 [2007] ECHR 700.

133 Ibid para 61.

134 (App No 8410/78), 13 December 1979.

${ }^{135}$ For example, see: Pudas v Sweden (App No 10426/83) (1987) 10 EHRR 380 para 241; Gudmundsson v Iceland (App No 23285/94) 17 January 1996; Størksen v Norway (App No 19819/92), 5 July 1994; Batelaan and Huiges $v$ Sweden (App No 10426/83) (1987) 10 EHRR 380.

136 (App No 33298/96), 21 October 1998. Citing Pudas v Sweden (App No 10426/83) (1987) 10 EHRR 380.

${ }^{137}$ Ibid.

${ }^{138}$ See fn 124 above; Bhasin (2012) 17 JR 226, 230.

139 (App No 11540/85), 8 March 1988.
} 
of the cases from the Van Marle line - shows that the $X$ proposition was referred to in the Swedish Government's submissions, but was not taken any further by the Commission itself.

Unfortunately, the confusion does not stop with the Commission, or the ECtHR's decisions in Marckx and JA Pye. Strasbourg jurisprudence has created a further divergence. In Edgar v United Kingdom ${ }^{140}$ the Court held the applicant's claim to property in goodwill 'based upon the profits generated by the business' is, essentially, a complaint 'in substance of loss of future income' which 'falls outside the scope of [A1P1]. ${ }^{, 41}$ Almost identical reasoning was subsequently applied by the ECtHR in a number of subsequent cases, ${ }^{142}$ which made its decision in Wendenburg $v$ Germany ${ }^{143}$ all the more surprising. In this case the Court considered a complaint that the removal of the applicant's rights of audience in the appeal courts, and the alleged subsequent loss of clientele this caused, breached A1P1. In coming to its decision, the Court found that, to the extent the complaint concerned a loss of future income, it fell outside the scope of A1P1, a decision that clearly corresponds with the case law discussed above. However, in what seems like direct conflict with its previous jurisprudence, it went on to say that $\mathrm{A} 1 \mathrm{P} 1$ 'extends to law practices and their clientele, as these are entities of a certain worth that have in many respects the nature of a private right and thus constitute assets and therefore possessions within the meaning of [A1P1].' Undoubtedly, this is a confusing and equivocal position to adopt ${ }^{144}$ as a legal practice, which it seems, in this context at least, means its brand and reputation, and its client base, do not

\footnotetext{
140 (App No 37683/97), 25 January 2000. The case concerned a challenge to the alleged impact of the UK handgun ban on the applicant's business.

${ }^{141}$ Ibid para 7.

${ }^{142}$ For example, see: Slough v United Kingdom (App Nos 37679 and 37682/97), 26 September 2000 para 7; Findlater $v$ United Kingdom (App No 38881/97), 26 September 2000 para 6; CEM Firearms Ltd v United Kingdom (App Nos 37674 and 37677/97) (2000) 30 EHRR CD156 para 7; London Armoury Ltd v United Kingdom (App Nos 37666, 37671, 37972, 37977, 37981 and 38909/97), 26 September 2000 para 6 f; Andrews v United Kingdom (App No 37657/97) (2000) 30 EHRR CD152 para 6.

143 (App No 71630/01), 6 February 2003.

${ }^{144}$ Bhasin (2012) 17(3) JR 226, 231; Acheson (2018) 10 JML 49, 70.
} 
have inherent worth distinct from the present value of the future income that they are expected to generate for the practice. Rather, they form part of the intangible pool of goodwill which is inextricably linked to the future economic benefits in the practice. ${ }^{145}$

\section{What this means for English law}

The equivocality of the Strasbourg jurisprudence has filtered down into English case law. In $R$ (Nicholds) v Security Industry Association ${ }^{146}$ Kenneth Parker QC considered that a business had a capital value or goodwill only if it was capable of being organised in a way that allowed future cash flows to be capitalised. ${ }^{147}$ In other words, goodwill would only constitute a possession if it is capable of being sold. This analysis has been the subject of subsequent approval, as demonstrated by Auld LJ's judgment in $R$ (Malik) $v$ Waltham Forest NHS Primary Care Trust ${ }^{148}$ in which he described it as 'powerful., 149

Malik concerned the unlawful suspension of Dr Malik from his Primary Care Trust's 'performers list', which resulted in him being unable to practise within the National Health Service. Consequently, it was alleged that his practice suffered a loss of goodwill, including reputation, as a result. Dr Malik was unable to sell the goodwill in his practice by virtue of statutory prohibition. ${ }^{150}$ Although, the issue did not arise in this case as Dr Malik's practice had no economic value due to the statutory prohibition on selling its goodwill, ${ }^{151}$ Auld LJ endorsed the marketability analysis for determining whether goodwill constitutes a possession under A1P1. ${ }^{152}$ According to Acheson, under this approach, corporate reputation

\footnotetext{
${ }^{145}$ Bhasin ibid 227 f, 231.

146 [2006] EWHC 1792 (Admin); [2007] ICR 1076.

${ }^{147}$ Ibid para $72 \mathrm{f}$.

148 [2007] EWCA Civ 265.

149 Ibid para 42. See also, Lord Bingham's judgment in Countryside Alliance v Attorney General [2007] UKHL

52 in which his Lordship stated that this interpretation was 'very convincing.'

${ }^{150}$ Ibid para 23.

151 Ibid.

152 Ibid para 40.
} 
should not be considered a possession as, according to Moses LJ, the reputation element of goodwill, although potentially valuable, is not marketable. ${ }^{153}$

On this interpretation, a company cannot sell its reputation, because the reputation is inseparable from the company itself. ${ }^{154}$ However, it is submitted that this analysis is flawed for two primary reasons. Firstly, it does not take into account companies that exist simply to licence their reputation. For example, car manufacturers tend to operate their dealerships on a franchise basis. The franchisee will 'purchase' the reputation of the car manufacturer in the form of a licence, yet the dealership will still operate under its own name. Indeed, many dealerships operate multiple franchises with different manufacturers. In this way, the reputation of the manufacturer and dealership are distinct. Secondly, as acknowledged by Rix $\mathrm{LJ}$, it is difficult to reconcile with the jurisprudence of the ECtHR. According to Rix LJ, distinguishing goodwill from future earnings prospects 'may turn out to be difficult, possibly even unworkable, given that the present-day value of any business will inevitably reflect its future profit-earning capacity.' ${ }^{155}$ He doubted whether a 'marketability' test was the answer, given the 'substantive distinction' between goodwill and future income drawn by the ECtHR, and because the Strasbourg Court had repeatedly found goodwill in the form of a professional's clientele, which was not readily marketable, to be a 'possession.' 156

\section{E Sitting on the fence and the mirror principle}

The Strasbourg Court has had opportunities to bring clarity to this situation but, unfortunately, has so far failed to do so, and is seemingly intent to sit on the fence. For example, in Malik v United Kingdom ${ }^{157}$ although the Court affirmed the Court of Appeal's

\footnotetext{
${ }^{153}$ Ibid para 85; Acheson (2018) 10 JML 49, 70.

${ }^{154}$ Acheson ibid. See also, D Rolph, Reputation, Celebrity and Defamation Law (2008) 21; K Craik, Reputation:

A Network Interpretation (2009) xvii.

155 Ibid para 65.

156 Ibid.

157 App No 23780/08 [2012] Med LR 270.
} 
decision that a right to practise a profession was not a possession under A1P1, it failed to address the issue of when goodwill could be. Rather, in determining that Dr Malik had goodwill in the form of his 'vested interest and his patient list', even though he was prevented from selling it, it seemed to suggest that 'marketability' was not a requirement. ${ }^{158}$ Regardless of this, the Court confusingly held that 'the question whether there is a possession in the present case is inextricably linked to the question whether there has been an interference.' Consequently, it avoided deciding whether the applicant's business interests were "possessions" under A1P1 by determining that, even if they were, there had been no interference with them. ${ }^{159}$ There was an equally equivocal outcome in Firma EDV Für Sie EfS Elektronische Datenverarbeitung Dienstleistungs GmBH v Germany ${ }^{160}$ in which the applicant, who was a 'legal person founded exclusively for business purposes', ${ }^{161}$ argued that its art 8 and A1P1 rights had been infringed by the failure of the German courts to protect it from statements made by another private party that had 'tarnished [its] reputation and ruined its economic foundation.' ${ }^{162}$ The Strasbourg Court decided, inter alia, to leave open the question of whether a company's reputation and goodwill constitute 'possessions' under A1P1, thereby attracting the protection of that article. ${ }^{163}$

Undoubtedly, the law in this area is a mess. It is subject to conflicting lines of case law and equivocal jurisprudence within those lines which, as stated by Bhasin, produce arbitrary and unclear outcomes. ${ }^{164}$ It seems that the preferred approach in England is that only an interference with 'capitalised' or 'marketable' goodwill engages the article, although, as argued above, this interpretation is flawed and is subject to opposing views. To the

\footnotetext{
158 Ibid para 99.

159 Ibid para 110.

${ }^{160}$ App No 32783/08 (ECtHR, 2 September 2014).

161 Ibid para 31.

162 Ibid para 18.

163 Ibid para 34.

${ }^{164}$ Bhasin (2012) 17 JR 226, 234.
} 
contrary, Strasbourg case law requires that 'goodwill' is separated from 'future income', albeit it does not provide any rational basis for doing so.

From an English law perspective, the House of Lords consistently interpreted the obligation imposed on judges to take Strasbourg jurisprudence into account in domestic proceedings, pursuant to sec 2 of the Human Rights Act 1998, strictly, meaning that English jurisprudence should 'mirror' the jurisprudence of the ECtHR. ${ }^{165}$ According to Lord Bingham in $R$ (on the application of Ullah) $v$ Special Adjudicator ${ }^{166}$ failure to follow 'clear and constant' Strasbourg jurisprudence would be unlawful under sec 6(1) HRA $1998,{ }^{167}$ unless there are 'special circumstances" ${ }^{168}$ that justify departure from that approach. ${ }^{169}$ Despite Lord Bingham's judgment in Ullah being the subject of both judicial ${ }^{170}$ and academic ${ }^{171}$ criticism, the mirror principle remains in place, which means that unless it can be persuasively argued that such 'special circumstances' exist, then the analysis of the European Court should be followed. Consequently, it is unfortunate that the ECtHR did not take the opportunity to provide a clear and unequivocal determination to this issue in either Malik or Firma. Had it have done so, pursuant to the mirror principle, it would have provided much needed clarity by way of a clear rationale that must, in principle at least, be followed.

${ }^{165} R$ (on the application of Quark Fishing Ltd) $v$ Secretary of State for Foreign and Commonwealth Affairs [2006] 1 AC 529 para 34 per Lord Nicholls. See also: J Lewis, The European Ceiling on Human Rights (2007) Public Law (PL) 720; P Wragg, A Freedom to Criticise? Evaluating the Public Interest in Celebrity Gossip after Mosley and Terry (2010) 2 JML 295, 314.

166 [2004] 2 AC 323.

${ }^{167}$ Sec 6(1) states: 'it is unlawful for a public authority to act in a way which is incompatible with a Convention right'; pursuant to sec 6(3) the definition of 'public authority' includes the courts.

${ }^{168}$ It is unclear what amounts to 'special circumstances'. See: Wragg (2010) 2 JML 295, 314.

${ }^{169}$ Wragg ibid at 314.

${ }^{170}$ In $R$ (on the application of Children's Rights Alliance for England) v Secretary of State for Justice [2013] EWCA Civ 34 at paras $62-64$ Law LJ stated that: '...I hope the Ullah principle may be revisited. There is a great deal to be gained from the development of a municipal jurisprudence of the Convention Rights, which the Strasbourg court should respect out of its own doctrine of the margin of appreciation, and which would be perfectly consistent with our duty to take account of (not to follow) the Strasbourg cases.'

${ }^{171}$ R Masterman, Taking the Strasbourg Jurisprudence into Account: Developing a 'Municipal' Law of Human Rights under the Human Rights Act (2005) 54 International and Comparative Law Quarterly (ICLQ) 907; Lewis (2007) PL 720. 


\section{Conclusion: a flawed approach and a way forward}

Despite the equivocal jurisprudence set out above, it is submitted that a company's reputation should, in fact, fall within the ambit of the right to protection of property pursuant to A1P1 of the ECHR. This conclusion is drawn from the following factors. Firstly, as argued throughout this article, the ability of businesses to be able to protect their reputation is not only vital for their health and prosperity, but also that of the communities within which they are located. The critical importance of corporate reputation within this context has recently been acknowledged by the NSW Government's Review of the Australian Defamation Act 2005 and is reflected by the approaches to corporate reputation adopted by a number of jurisdictions. ${ }^{172}$ Secondly, A1P1 explicitly applies to 'legal persons.' Thirdly, as discussed in section IV, a company's reputation is based on the concept of reputation as property. As advocated in that section, in line with Post's social foundations of reputation, there is a strong conceptual basis for reputation to be considered property in the fullest sense. Failing that, at the very least, it supports the argument that corporate reputation qualifies as a form of quasiproperty. Fourthly, although admittedly a weaker argument in light of the conflicting case law considered in section VI, there is a clear line of Strasbourg jurisprudence, pursuant to Van Marle, that recognises that A1P1 protects the right to conduct a business and the commercial goodwill and clientele built up by the company's work. As Oster states, '[b]y virtue of its commercial nature, a trading company's reputation, that is, its deserved 'good name', neatly fits in this context. ${ }^{173}$

\footnotetext{
172 See section III.

${ }^{173}$ Oster (2011) 2 JETL 255, 263. As Oster states, this also corresponds with the view of the German Federal Court of Justice that determines that a company's reputation, as protected by the 'right to an established and active business' as a derivation of art 12 Basic Law (occupational freedom) in conjunction with art 14 Basic Law (guarantee of property).
} 
As argued in section $\mathrm{V}$, recognising that corporate reputation is protected by A1P1 has significant repercussions. Although the qualifications to art 10(1) ECHR pursuant to art 10(2) allow the respective State to justifiably interfere with the right to freedom of expression 'for the protection of the reputation or rights of others,' the State is burdened with justifying any such interference based on tests of necessity and proportionality. Thus, as acknowledged by Fenwick and Phillipson, art 10(2) is based on the 'albeit rebuttable' presumption that art 10(1) prevails over the (non-Convention) interests of others in the first place. ${ }^{174}$ To the contrary, recognising reputation as a positive aspect of another human right, in this case property, requires a fair balancing of conflicting equal rights rather than presuming that art 10(1) prevails. ${ }^{175}$ Additionally, as discussed in section V, States have a positive obligation to ensure the protection of rights enshrined in the ECHR between private parties. This imposes an obligation on them to take positive action to protect an individual from interference by other parties. According to Oster: ${ }^{176}$

It is...important to notice that perceiving a corporation's reputation as being rooted in property [in A1P1], does not coercively entail that a company deserves less protection for its reputation than a human being. To attach to corporate reputation a mere 'instrumental purpose' and thereby argue for a lesser degree of protection than for a human being's reputation misconceives the significance of the protection of property as a fundamental right.

Finally, it is arguable that attaching a human rights value to a corporation's reputation acts as an effective rejoinder to the argument that the possible 'mismatch of resources' ${ }^{177}$ or 'inequality of arms' ${ }^{178}$ between an affluent corporate claimant and a small defendant

\footnotetext{
${ }^{174}$ H Fenwick/ G Phillipson, Media Freedom under the Human Rights Act (2006) 1070. See also Oster ibid.

${ }^{175}$ Fenwick/Phillipson and Oster ibid. See also: A Nicol QC/ G Millar QC/A Sharland, Media Law and Human Rights (2nd edn 2009) para 5.21.

176 Oster ibid..

${ }^{177}$ Ministry of Justice, Draft Defamation Bill, Consultation Paper CP3/11, March 2011 para 177.

${ }^{178}$ House of Commons Culture, Media and Sport Committee, Press Standards, Privacy and Libel, Second Report of Session 2009-2010, Volume I, HC 362-I para 138.
} 
newspaper or an impecunious individual justifies making it more difficult, or even impossible, for corporations to sue for defamation. The threat of costly and protracted legal proceedings by company claimants, and the stifling effect on public debate that results from such proceedings, should be addressed by reform to civil litigation funding and costs, rather than limiting a company's substantive rights. ${ }^{179}$ Dealing with the issue in this way would serve to alleviate some of the concerns of a 'chilling effect' on free speech that may stem from corporate reputation being the subject of positive ECHR rights by virtue A1P1. At the same time, it offers a mechanism for bodies trading for profit to protect what is not only a valuable asset, but is also, particularly in the context of the very many smaller businesses, vitally important for their survival. Thus, it is submitted that the conceptual foundations of property, and A1P1, dictate that businesses' reputations are deserving of protection against defamatory imputations. In the modern-day world of neo-liberal economics, it is not unrealistic to treat corporate reputation as a form property for the purposes of A1P1. It would then follow that real benefits (as set out in section $\mathrm{V}$ of this article) would accrue to businesses, regardless of size, in the sense that they would have a positive ECHR right which the State would be bound to safeguard. Furthermore, this would enable businesses to take appropriate enforcement action against the State to enforce the right. Consequently, and in conclusion, in this context, any legislation akin to the Australian Defamation Act 2005, discussed above in section III, should be regarded as a violation of the right to reputation as property pursuant to A1P1. ${ }^{180}$ Indeed, if the right to reputation was unequivocally treated as an aspect of property, and therefore subsumed within the ambit of A1P1, this would potentially subject section 1 of the Defamation Act 2013 to human rights scrutiny due to the difficulty in demonstrating actual or likely serious financial loss which, due to its complete

\footnotetext{
${ }^{179}$ Oster (2011) 2 JETL 255, 264.

${ }^{180}$ Ibid $264 \mathrm{f}$.
} 
lack of clarity, and the confusion it has generated is, arguably, an impediment to justice. ${ }^{181}$ In turn, this could open the door for possible reform of the provision to ensure its compliance with the ECHR.

Endnote: The authors would like to thank JETL's anonymous reviewers for their helpful comments on earlier drafts of this paper. The usual disclaimer applies.

${ }^{181}$ For detailed discussion as to the uncertainty, confusion and general lack of clarity generated by this provision, see generally: Coe (2015) JBL (4) 313; Coe (2013) 18 Comms Law 112; P Coe, The Defamation Act 2013 and CPR 3.4 and 24: A Sting in Causation's Tail (2014) 25 Entertainment Law Revue 93. 